\title{
STUDY ON PERFORMANCE AND SOME ECONOMIC PARAMETERS DURING DIFFERENT MARKETING AGE OF BROILERS
}

\author{
SHILAN ARAM AKARM ${ }^{1}$; ROZHGAR BAYZ SAEED ${ }^{3}$; SHAHLA M. SEAD KIRKUKI ${ }^{3}$; \\ NASSRIN HASSAN AZIZ ${ }^{4}$ and HEMIN NURADDEN MOHAMMED ${ }^{5}$ \\ ${ }^{1}$ Poultry, Poultry Management, Assist. Lecturer, Sulaimni \\ ${ }^{2}$ Poultry, Poultry Nutrition, Lecturer, Sulaimni \\ ${ }^{3}$ Poultry, Poultry Management and Production, Lecturer, Sulaimni \\ ${ }^{4}$ Poultry, Poultry Nutrition, Assist. Lecturer, Sulaimni \\ ${ }^{5}$ Poultry, Poultry Management, Lecturer, Sulaimni
}

Received: 30 October 2016; Accepted: 12 December 2016

\begin{abstract}
This study was conducted at poultry farm in Bakrajo- Animal production department, Faculty of Agriculture Sciences, Sulaimani University during October and November 2013 (from 06/10/2013 to 02/12/2013). A total one hundred (120) one-day hybrids broiler chicks (Ross 308) (50 Male and 50 Female) were used in this experiment. The chicks were equally distributed into 10 experimental groups through 10 separated cages of $1.5 \times 2 \mathrm{M}$ each which provides $0.3 \mathrm{~m}^{2}$ per bird. Each cage contains 10 birds. At the starting of the marketing age (42 days), all birds were fed ad libitum on standard diet based on corn- soybean meal and contain $19.5 \%$ CP and $3150 \mathrm{Kcal} \mathrm{ME} / \mathrm{Kg}$. chicks were subjected to fed ad libitum with free access to fresh water throughout experimental period. The experimental period extended for 8 weeks (56 days) to measure carcass traits including dressed carcass, different pieces scheme and weights of internal organs. The production characteristics were measured at (49days) and (56 days), also (10) birds were slaughter at these two ages. The effect of marketing on characteristics related to productive performance for slaughter weight and different cutting parts was measured from the results of this work it can be concluded that the effect of ages and gender as well as interaction between them had significant effect on the live body weight (g), average of feed consumption, average of weight gain and also dressing percentage of broiler, but the age and gender and interaction among them didn't affect significantly on mortality percentage during the different marketing ages (49 and 56 days).
\end{abstract}

Key Words: Performance and Economic Parameters, Marketing, Age, Broilers.

\section{INTRODUCTION}

Growth performance of broiler chickens has been increased spectacularly over the last 30 years mainly due to the genetic progress, improvements of nutrition and controlled environment so that it takes only 33 days to reach finishing body weight of about $2 \mathrm{~kg}$ (Wilson, 2005). Unfortunately this growth rate is accompanied by increased body fat deposition, high mortality and high incidence of metabolic diseases and skeletal disorders (Zubair and Leeson, 1996).

Genetic improvement, in addition to maximizing live performance in poultry production, has allowed a reduction of age to market. During the last decades, eating habits have globally changed, with a strong

Corresponding author: Dr. ROZHGA RBAIZ SAEED

E-mail address: rozhgarbayzesaeed@yahoo.com

Present address: Poultry, Poultry Nutrition, Lecturer, Sulaimni larger birds present higher yield (Mendes, 1993). Therefore, according to literature, increasing market age affects production efficiency, which may result in higher production costs. From the processors' perspective, the higher added value obtained when trading meat cuts has justified this increase in market age (Schmidt, 2008). Zoltán (2010) underlined that market demands and economic potentials do not determine merely the volume of activities and their cost-benefit relations, but also the used type and body weight along with market age, the method of processing. Product types and packaging. During the last decades, eating habits have globally changed, with a strong preference for meat cuts and processed meat, and consequently the market of chicken cuts has exceeded the whole-bird market (Schmidt, 2008).

The character that determines how much the poultry project is success, so should taking care of this character because the increased of mortality percentage led to less profit specially broiler. The 
percentage of mortality character considers very important for poultry projects including broiler production. So that, the less amount of mortality percentage considering a Good economic indicator as well as successes from administrating, feeding and medical care aspects (Sameer, 2009). The objective of this study were to investigate the effect of marketing age and gender on growth Performance and production carcass traits of broiler.

\section{MATERIALS AND METHODS}

This study was conducted at poultry farm in BakrajoAnimal production department, Faculty of Agriculture Sciences, Sulaimani University during October and November 2013 (from 06/10/2013 to 02/12/2013). A total one hundred (120) one-day hybrids broiler chicks (Ross 308) (50 Male and 50 Female) were used in this experiment. The chicks were equally distributed into 10 experimental groups through 10 separated cages of $1.5 \times 2 \mathrm{M}$ each which provides $0.3 \mathrm{~m}^{2}$ per bird. Each cage contains 10 birds. At the starting of the marketing age (42 days), all birds were fed ad libitum on standard diet based on corn- soybean meal and contain $19.5 \% \mathrm{CP}$ and 3150 Kcal ME/Kg. chicks were subjected to fed ad libitum with free access to fresh water throughout experimental period. The experimental period extended for 8 weeks (56 days) to measure carcass traits including dressed carcass, different pieces scheme and weights of internal organs. At the end of the experiment, the production index for different ages were compared to Economic feasibility study for the research project. The chicks weighed upon the age of 42 days; the chicks were weighed in each repeater within a Treatment to get the average body weight. Weight gains were calculated for each repeater after the end of each period. Feed consumption was recorded during each period for each repeater in the experiment also at the end of the periods (49 and 56 days), that the weight of the feed given to the birds of the repeater during the period minus the birds which mortality occurred and by using the following equation Weight:

Average daily feed consumption (g / bird) =Feed amount represents the consumer during the period / the number of live chickens at the end of the period $x$ the numbers of days for the period $\times$ The number of days in which the Mortality birds fed (Fayth and Naji, 1989).

The number of kilograms of feeds that consummated by the birds are necessary to achieve the carcasses weight gained, was calculate according to the following equation:

Food conversion factor $=$ The average amount of consumer fodder by the live birds in a given period/
The average weight gain of live birds in the same period.

At the end of each period of the experiment when the ages are (49 and 56) days was chosen (10) birds of all repeaters ( 5 birds of each gender), where the birds were weighed individually before slaughter, then slaughtered and cleaned and removed, including internal organs. Then weigh the carcass to find the percentage of dressing according to the following equation:

$\%$ Dressing percentage $=$ Ready carcass weight $(\mathrm{g})+$ internal giblets weights (g)/ Live body weight (g)

Mortality Percentage: It has been registered number Mortality per day per treatment, depending on the percentage of Mortality according to the following equation: Mortality Percentage $=$ Number of mortality birds during the period / The total number of chicks in the beginning of the period $\times 100$.

Measures of Index production:

To express the efficiency of the performance of the herds of broiler chickens used several measures to see the economic value of the project as cited Nagi et al. (2006), as in the following equations: Measure of Index production $=$ Average body weight $(\mathrm{g}) \times$ vital ratio/ Number of days of education $\times$ food conversion efficiency $\times 10$. Note that the vital ratio $=100-$ the proportion of mortality.

\section{The proportion of different carcass cutting parts}

Calculated weights cutting parts percentage of carcass weight according to the following equation: The proportion of the carcass pieces $=$ Piece weight $(\mathrm{g}) /$ Complete carcass weight $(\mathrm{g}) \times 100$. Carcass was cut up into cutting major (breast and thigh).

\section{Statistical analysis:}

Data analysis was conducted using the factor experience with two factors $(2 \times 3)$ in the entire design random Factorial Experiment in- CRD following XL stat program has been tested and the results according to Duncan test multi-term (Duncan, 1955) below the level of $5 \%$ probability. The data analysis conducted according to the following mathematical equation:

Yijk $=\mu+A i+B j+(A B) i j+e i j k$

Whereas:

Yijk: the value of viewing the experimental unit (k), which took the level (i), of the first factor (A) age and level (j) of the second factor (B) sex.

$\mu$ : the value of the overall average 
Ai: the value of the effect-level (i) of factor A (42.49 ages three and 56).

$\mathrm{Bj}$ : the value of the effect-level (j) of factor B (sex). $(A B) \mathrm{ij}$ : the value of interaction effect between the level of (i) of factor A (age) and level (j) of the world (B) sex.

eijk: Pilot error and random private value of these experimental module that is a mistake distributed normal and independent distribution of an average year is equal to zero and variance o.

\section{RESULTS}

Table (1) shows the effect of age and sex, and their interaction between them on living body weight $(\mathrm{g})$ of broilers. Age and sex of birds as well as the interaction between them have a significant effect ( $p$ $<0.05$ ) on the live body weight at the age of 49 and 56 days. There were significant differences between the different ages, as well as for both sexes and male gave higher body weights.

Table 1: Live body weight ( $g$ ) of birds as influenced by age, sex and interaction between them (mean $\pm \mathrm{SE}$ ).

\begin{tabular}{|c|c|c|c|c|}
\hline \multicolumn{2}{|c|}{ Treatments } & \multicolumn{2}{|c|}{ Age } & \multirow[t]{2}{*}{ Sex (mean) } \\
\hline & & 49 & 56 & \\
\hline \multirow[t]{2}{*}{ Sex } & Male & $3954.20^{\mathrm{b}} \pm 122.970$ & $4555.00^{\mathrm{a}} \pm 260.84$ & $4254.60^{\mathrm{a}} \pm 168.84$ \\
\hline & Female & $3028.40^{c} \pm 198.069$ & $3515.00^{\mathrm{bc}} \pm 99.25$ & $3271.70^{\mathrm{b}} \pm 132.23$ \\
\hline \multicolumn{2}{|c|}{ Age (mean) } & $3491.30^{\mathrm{b}} \pm 189.439$ & $4035.00^{\mathrm{a}} \pm 217.61$ & \\
\hline
\end{tabular}

Different letter for the age and sex as well as the interaction between them refers to the existence of significant differences between the treatments $(\mathrm{p}<0.05)$.

Table (2) showed that, the impact of age, gender, as well as the interaction between them on the average of feed consumption during the last two weeks of raising (49-56 days of ages). The average feed consumption by the male was (1609.89 and 2406.80 g) respectively. However, the average of female's feed consumption was (1411.04 and $1406.30 \mathrm{~g})$ at two ages (49 and 56) day respectively. As well as the effect of sex in general be significantly $(p<0.05)$ on average feed consumption during the week, with the average feed consumption by the male was $(2008.35$ g) during the duration of the experiment, but the average feed consumed by a female was (1408.67) during the duration of the experiment.

Table 2: Weekly feed consumption ( $\mathrm{g}$ ) of broiler as influenced by age, sex and interaction between them (mean $\pm \mathrm{SE}$ ).

\begin{tabular}{|c|c|c|c|c|}
\hline \multirow{2}{*}{ Treatments } & & \multicolumn{2}{|c|}{ Age } & \multirow{2}{*}{ Sex (mean) } \\
\hline & & 49 & 56 & \\
\hline \multirow{2}{*}{ Sex } & Male & $1609.90^{\mathrm{b}} \pm 94.971$ & $2406.80^{\mathrm{a}} \pm 180.475$ & $2008.35^{\mathrm{a}} \pm 170.99$ \\
\hline & Female & $1411.04^{\mathrm{b}} \pm 207.75$ & $1406.30^{\mathrm{b}} \pm 163.725$ & $1408.67^{\mathrm{b}} \pm 114.87$ \\
\hline Age (mean) & & $1510.47^{\mathrm{b}} \pm 101.689$ & $1906.55^{\mathrm{a}} \pm 208.215$ & \\
\hline
\end{tabular}

Different letters for the age and sex as well as the interaction between them refers to the existence of significant differences between the Treatment $(\mathrm{p}<0.05)$.

Results of the table (3) shows the presence of significant effect $(p<0.05)$ of sex and the interaction between sex and age on average weight gain during the various stages of marketing age (49 and 56 days). For the reconstruction of birds there are significant differences between male and reconstruction showed the highest increased by weight compared to the female. As well as the effect sex in general be significantly ( $p<0.05$ ) on average weight gain during the week, with the average increase the weight by the 
male was (812.300) during the duration of the experiment.

Table 3: Body weight gain $(\mathrm{g})$ of broiler as influenced by age, sex and interaction between them (mean $\pm \mathrm{SE}$ ).

\begin{tabular}{ccccc}
\hline \multirow{2}{*}{ Treatments } & & \multicolumn{2}{c}{ Age } & Sex (mean) \\
\cline { 3 - 5 } & & 49 & 56 & \\
\hline \multirow{2}{*}{ Sex } & Male & $644.60^{\mathrm{b}} \pm 43.65$ & $980.00^{\mathrm{a}} \pm 83.89$ & $812.30^{\mathrm{a}} \pm 71.50$ \\
\cline { 2 - 5 } & Female & $584.10^{\mathrm{b}} \pm 77.87$ & $511.40^{\mathrm{b}} \pm 50.11$ & $547.75^{\mathrm{b}} \pm 45.29$ \\
\hline Age (mean) & & $614.35^{\mathrm{a}} \pm 43.26$ & $745.70^{\mathrm{a}} \pm 90.67$ & \\
\hline
\end{tabular}

Different letters for sex as well as the interaction between sex, age, indicate the existence of significant differences between the treatment $(\mathrm{p}<0.05)$.

Table (4) illustrated the significant effect $(\mathrm{p}<0.05)$ of sex and the interaction between sex and age on the feed conversion ratio during the various stages of marketing age (49 and 56 days). Since the feed conversion ratio of male were (2.52 and 2.45) at two marketing ages (49 and 56) days respectively, but the feed conversion ratio by a female up to (2.39 and 2.72) at two marketing ages (49 and 56) daysrespectively. As well as the effect of sex was significantly affected $(\mathrm{p}<0.05)$ on feed conversion ratio during the week as the feed conversion ratio by the male was (2.01) during the whole experimental period, but the feed conversion ratio by a female was (2.55).Age in general had low significant effect of feed conversion ratio (2.42 and 2.58) during two different marketing age (49 and 56) days respectively.

Table 4: Feed conversion ratio indices of broiler as influenced by age, sex and interaction between them (mean $\pm \mathrm{SE}$ ).

\begin{tabular}{|c|c|c|c|c|}
\hline \multirow{2}{*}{\multicolumn{2}{|c|}{ Treatments }} & \multicolumn{2}{|c|}{ Age } & \multirow{2}{*}{ Sex (mean) } \\
\hline & & 49 & 56 & \\
\hline \multirow{2}{*}{ Sex } & Male & $2.39^{\mathrm{b}} \pm 0.09$ & $2.45^{\mathrm{b}} \pm 0.08$ & $2.01^{\mathrm{b}} \pm 0.05$ \\
\hline & Female & $2.45^{\mathrm{a}} \pm 0.06$ & $2.72^{\mathrm{a}} \pm 0.06$ & $2.55^{\mathrm{a}} \pm 0.075$ \\
\hline \multicolumn{2}{|c|}{ Age (mean) } & $2.41^{\mathrm{b}} \pm 0.44$ & $2.59^{\mathrm{a}} \pm 0.07$ & \\
\hline
\end{tabular}

Different letters for sex as well as the interaction between sex, age, indicate the existence of significant differences between the transactions under the level of the probability $(\mathrm{p}<0.05)$.

The table (5) shows the presence of significant effect ( $\mathrm{p}<0.05)$ of sex and the interaction between sex and age on the production characteristic index through the various stages of marketing age (49 and 56 days).

Table 5: The effect of age, sex and the interaction between them on the production index of broiler chickens (average $\pm \mathrm{SE}$ ).

\begin{tabular}{|c|c|c|c|c|}
\hline \multirow{2}{*}{\multicolumn{2}{|c|}{ Treatments }} & \multicolumn{2}{|c|}{ Age } & \multirow{2}{*}{ Sex (mean) } \\
\hline & & 49 & 56 & \\
\hline \multirow{2}{*}{ Sex } & Male & $225.29^{\mathrm{b}} \pm 11.30$ & $266.57^{\mathrm{a}} \pm 17.07$ & $245.93^{\mathrm{a}} \pm 11.85$ \\
\hline & Female & $181.45^{\mathrm{c}} \pm 10.42$ & $184.79^{c} \pm 5.26$ & $183.12^{\mathrm{b}} \pm 5.53$ \\
\hline \multicolumn{2}{|c|}{ Age (mean) } & $203.37^{\mathrm{a}} \pm 10.29$ & $225.68^{\mathrm{a}} \pm 16.02$ & \\
\hline
\end{tabular}

Different letters for sex as well as the interaction between sex, age, indicate the existence of significant differences between the Treatments under the level of the probability $(\mathrm{p}<0.05)$. 
Results of the table (6), indicated that both age and sex, as well as the interaction between them had a significant effect $(\mathrm{p}<0.05)$ on the dressing percentage of broiler at age of 49 and 56 days. The dressing percentages of femaleswere (83.11 and $84.35 \%)$ at two ages (49 and 56days) respectively.

Table 6: The effect of age, sex and the interaction between them on the carcass traits broiler chicks (mean $\pm \mathrm{SE}$ ).

\begin{tabular}{|c|c|c|c|c|c|c|c|c|}
\hline \multirow{2}{*}{\multicolumn{2}{|c|}{ Treatment }} & \multicolumn{7}{|c|}{ Age (49 days) } \\
\hline & & Dressing & Breast & Thigh & Heart & Liver & Wings & Gizzard \\
\hline \multirow{2}{*}{ Sex } & Male & $85.22^{\mathrm{bc}} \pm 0.49$ & $29.77^{\mathrm{b}} \pm 0.90$ & $11.40^{\mathrm{a}} \pm 1.26$ & $0.62^{\mathrm{a}} \pm 0.06$ & $2.24^{\mathrm{a}} \pm 0.13$ & $8.57^{\mathrm{a}} \pm 0.09$ & $2.40^{\mathrm{a}} \pm 0.06$ \\
\hline & Female & $83.11^{c} \pm 2.62$ & $31.85^{\mathrm{ab}} \pm 0.95$ & $12.90^{\mathrm{a}} \pm 0.69$ & $0.64^{\mathrm{a}} \pm 0.05$ & $2.53^{\mathrm{a}} \pm 0.14$ & $9.30^{\mathrm{a}} \pm 0.41$ & $2.70^{\mathrm{a}} \pm 0.23$ \\
\hline
\end{tabular}

Table 7: The effect of age, sex, and the interaction between them on the carcass traits broiler chicks (mean \pm $\mathrm{SE})$.

\begin{tabular}{|c|c|c|c|c|c|c|c|c|}
\hline \multirow{2}{*}{\multicolumn{2}{|c|}{ Treatment }} & \multicolumn{7}{|c|}{ Age (56days) } \\
\hline & & Dressing & breast & Thigh & Heart & Liver & Wings & Gizzard \\
\hline \multirow{2}{*}{$\operatorname{sex}$} & Male & $89.76^{\mathrm{a}} \pm 0.37$ & $31.52^{\mathrm{ab}} \pm 0.54$ & $12.14^{\mathrm{a}} \pm 0.31$ & $0.54^{\mathrm{a}} \pm 0.04$ & $2.40^{\mathrm{a}} \pm 0.08$ & $8.91^{\mathrm{a}} \pm 0.14$ & $2.28^{\mathrm{a}} \pm 0.24$ \\
\hline & Female & $84.35^{\mathrm{b}} \pm 0.39$ & $32.83^{\mathrm{a}} \pm 0.52$ & $11.533^{\mathrm{a}} \pm 0.23$ & $0.52^{\mathrm{a}} \pm 0.03$ & $2.56^{\mathrm{a}} \pm 0.14$ & $8.93^{\mathrm{a}} \pm 0.44$ & $2.40^{\mathrm{a}} \pm 0.14$ \\
\hline
\end{tabular}

\section{DISCUSSION}

It should be emphasized that poultry industry and market features, due especially to the lower volume of slaughter during the Christmas and New Year periods are difficult tocalculate precisely. The number determined by theoretical calculations could be merely workable if the activities of chick transporting and slaughtering-processing plants could be precisely coordinated with chick placement and slaughter periods.

The body weight is considered one of the most important economical characteristics which affected on the poultry projecting production because of their huge effects in total revenues for production projects specially broiler (Ahmed, 2006). The character of body weight gain it is necessary if the purpose is meat production, and could get the maximum amount of gained body weight when the perfect atmosphere is available for the birds. This became axioms of broiler trade requirements and it is well known that heating and high temperature over the normal limit affected negatively over birds and become stressful for expressing its production characteristics (Anwar, 2010). Feed conversion ratio increased with on increasing age of birds in both sexes. The male birds should have a lower FCR in general than that of females due to their higher genetic potential for body weight gain. According to Leeson (2000), the FCR in female broilers is usually higher than that in male birds at corresponding weight after about 30 days of age. Leeson (2000). The food conversion efficiency considers the best measure of the viability of broiler to conversion intake feeds to increasing live weight, and the broiler breeder goal is getting quick growth of the broiler to reach the market weight in earlier time with minimal amount of feed consumption, This give a good economic indicator for meat production projects (Sameer, 2009). Feed consist $70 \%$ of total cost of poultry projects so the feed consumption takes in consideration when breeding broiler and the feed consumption character is one of the most important characters for breeding broiler it is the key success in the production process. The feed consumption decreases by high temperature environment, which affected in general on the production performance. Is the character that determines how much the poultry project is success, so should be taking care of this character because the increased of mortality percentage led to less profit specially in broilers. The percentage of mortality character considers very important for poultry projects including broiler production. So that, the less amount of mortality percentage considering a Good economic indicator as 
well as successes from administrating, feeding and medical care aspects (Sameer, 2009).

\section{RECOMMENDATIONS}

From the results of this study, it can be we can recommend the following points:

1. Conduct a study on reducing the period of breeding to broiler chickens.

2. Conduct a study on reducing the cost of feed to breed broiler chickens.

\section{REFERENCES}

Ahmed Abdul-Ghany, (2006): Study of some factors effect on poultry production. MSc thesis, University of Azhar, fac of agnc.

Anwar Mohammed Younis, (2010): Effect of stocking densities, number of feeders and different enviromental temperature and there intreaction on some productive performance and physiological characteristics of broiler chickens. MSc thesis, University of Mosul.

Duncan, D.B. (1955): Multiple range and multiple F test Biometrics 11:1- 42 .

Fayad, H.A.A. and Naji, S.A.H. (1989): Technology Poultry Products. The first edition, the printing press directorate of the ministry of higher education Baghdad.

Leeson (2000): Is feed efficiency still a useful measure of broiler performance. [on line]. [Accessed on 10.03.2009]. Available athttp:// www.omafra.gov.on.ca/english/livestock/poult ry/facts/efficiency.htm

Mendes, AA. (1993): Efeito da linhagem e idade de abatesobre o rendimentodecarcaça de frangos de corte. Revista Sociedade Brasileirade Zootecnia 22(3):466-472.

Naji, S.S.H. (2006): Commercial broiler production manual. Technical bulletin. Iraq Int. of Poult. Sci. accociation.

Sameer Hameed Majeed (2009): Effect of partial Replacement of Soybean Meal by Vicia Sativa Seeds on Broiler Performance. MSc thesis, University of Mosul.

Schmidt, G.A. (2008): The Effect of Broiler Market Age on Performance Parameters and Economics, Revista Brasileira de Ciência Avícola, vol. 10(4) pp. 223-225, Fundaçãomapinco de ciência e tecnologiaavícolas, campinas, available at: http://www.redalyc.org/articulo.oa?id=179713 996005.

Wilson, $M$ (2005): Production focus (in; balancing genetics, welfare and economics in broiler production). Vol1 (no. 1).pp 1.publication of cobb-vantress, inc.

Zoltán, P. (2010):jóindítás, eredményeshizlalás, baromfiágazat, vol. 10(4), pp. 36-42, gbt press, budapest.

Zubair, A.K. and leeson, S. (1996): Compensatory growth in the broiler chicken: a review. World's poult. Sci. 52:189-201.

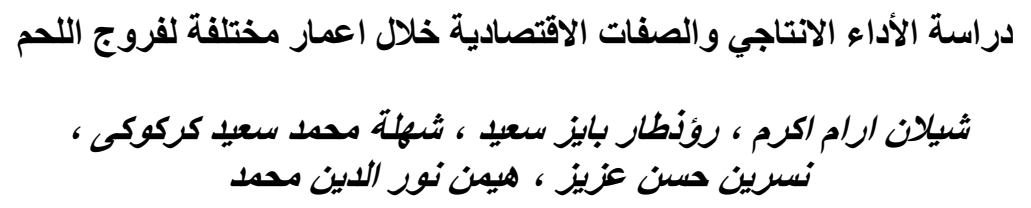

Email: rozhgarbayzesaeed@yahoo.com Assiut University web-site: www.aun.edu.eg

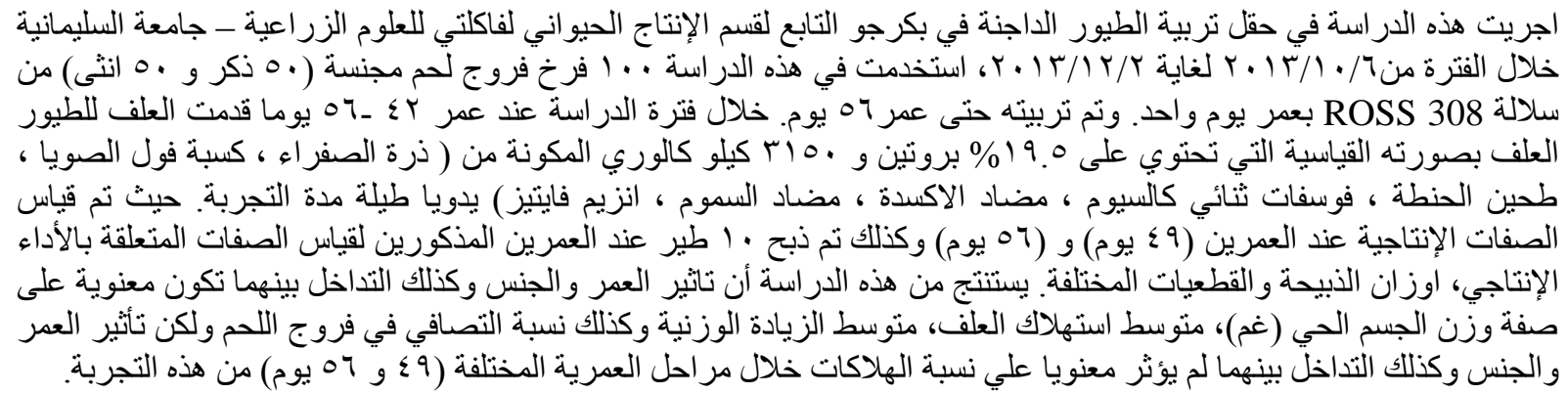

